\title{
Implications Of Changes In Tax Rates For Firm Debt Levels: Evidence From The 1986 Tax Reform Act
}

Terrance Jalbert, (jalbert@hawaii.edu) University of Hawaii at Hilo

\begin{abstract}
In a recent paper, Jalbert (2002) develops and tests valuations equations for firms that are subject to passthrough taxation and for firms that are subject to double taxation. This work is extended by Jalbert and Dukes (2003) who examine the implications of a zero percent tax rate on dividend income. In this paper, we extend this line of work by developing equations for the implied changes in firm capital structure around a change in tax regime. The results show that firms change their capital structures in predictable ways when tax rates change. These results are important for determining likely changes in firm policy around future tax regime changes.
\end{abstract}

\section{INTRODUCTION}

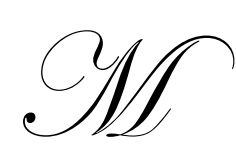

any models have been developed to value firms and determine optimal capital structures for firms. Among the most famous of these models is developed in Miller (1977). Miller (1977) developed his model utilizing a number of assumptions including assumptions about dividends and cash flow growth. Specifically, Miller (1977) assumed that dividends are delayed for a sufficient amount of time so that the effective personal tax rate on income from equity ownership is zero. This assumption implies that firms retain a substantial amount of cash flows within the firm. He also utilized a perpetuity approach to develop his model. The perpetuity approach implies that the firm's NOI does not change from year-toyear. Jalbert (2002) argues that the combination of assumptions used by Miller are not consistent. Earnings retention implies a corresponding increase in the firm's asset base, which in turn implies NOI growth in subsequent years. NOI growth violates the perpetuity assumption that cash flows remain constant from year-to-year. Thus the combination of assumptions utilized by Miller (1977) is unlikely to occur. Jalbert (2002) developed a model based on the work of Miller (1977) that addresses the problematic assumptions of Miller. Jalbert (2002) assumes that all cash flows are perpetuities, implying that the cash flows of the firm do not grow and that that all cash flows of the firm, except those cash flows necessary to replace depreciating equipment on a one-for-one basis, are paid out as dividends. The assumptions utilized by Jalbert (2002) are internally consistent and thus offer an improvement over the work of Miller (1977). Utilizing these assumptions, Jalbert (2002) develops equations for both firms subject to the pass-through taxation system (PTF) and for firms subject to their double taxation system (DTF). The equations are developed for both the unlevered (a firm that does not borrow money) and levered firm (a firm that borrows money). The equations for the levered and unlevered DTF and the levered and unlevered PTF respectively are given by:

$$
\begin{aligned}
V^{U D} & =\frac{E(N O I)\left(1-T_{C}\right)\left(1-T_{P S}\right)}{\rho} \\
V^{L D} & =\frac{E(N O I)\left(1-T_{C}\right)\left(1-T_{P S}\right)}{\rho}+\frac{K d D\left[\left(1-T_{P B}\right)-\left(1-T_{P S}\right)\left(1-T_{C}\right)\right]}{K_{b}}, \\
V^{U P} & =\frac{E(N O I)\left(1-T_{P S}\right)}{\rho}
\end{aligned}
$$




$$
V^{L P}=\frac{E(N O I)\left(1-T_{P S}\right)}{\rho}+\frac{K d D\left[\left(1-T_{P B}\right)-\left(1-T_{P S}\right)\right]}{K_{b}} .
$$

Where:

$$
V^{U D}=\text { the value of an unleverd DTF }
$$

$V^{L D}=$ the value of a levered DTF

$V^{U P}=$ the value of an unlevered PTF

$V^{L P}=$ the value of a levered PTF

$T_{P S}=$ the personal tax rate on income from stocks

$T_{P B}=$ the personal tax rate on income from bonds

$T_{C}=$ the entity-level tax rate

$N O I=$ the net operating income of the firm

$K_{d}=$ the interest rate on debt

$D=$ the book value of the debt outstanding

$\rho=$ the discount rate for an all-equity firm of equivalent risk

$K_{b}=$ the risk-free rate of interest

$E=$ the expectations operator

The above equations imply a gain from leverage for the DTF and PTF respectively of:

$$
\begin{aligned}
G^{L D} & =\frac{K_{d} D\left[\left(1-T_{P B}\right)-\left(1-T_{C}\right)\left(1-T_{P S}\right)\right]}{K_{b}} \\
G^{L P} & =\frac{K_{d} D\left[\left(1-T_{P B}\right)-\left(1-T_{P S}\right)\right]}{K_{b}}
\end{aligned}
$$

Miller (1977) argues that while there is an optimal capital structure for the economy as a whole, there is not an optimal capital structure for individual firms. Jalbert (2002) on the other hand argues that there is an optimal capital structure for individual firms. Jalbert (2002) finds that firms subject to pass-through taxation have a higher value per dollar of net operating income than firms subject to double taxation. Moreover his results suggest that this difference is mitigated when firms use higher levels of debt in their capital structures. Jalbert (2002) also finds that DTFs use more debt in their capital structures, after controlling for firm size and risk, than PTFs. The results of the test indicate that DTFs are not more efficient in transforming sales into net operating income than PTFs, contrary to what was expected, leaving open the question of why DTFs continue to exist in the economy. Several alternative explanations are offered for the continued existence of DTFs.

Jalbert and Dukes (2003) extend the work of Jalbert (2002) by examining the implications of the Jalbert (2002) model with regard to the Bush tax proposal to eliminate taxes on dividend income. They develop modified equations and argue that the value of DTFs would increase relative to their PTF counterparts if the tax proposal were adopted. They argue that DTFs would reduce their reliance on debt and increase their reliance on equity financing if the Bush proposal were adopted. Moreover, firms should be expected to increase their dividend payout ratios.

In this paper, we extend the work of Jalbert (2002) and Jalbert and Dukes (2003) by explicitly modeling the change in capital structure expected as a result of a change in tax regimes. The implied changes are tested using a paired sample of master limited partnerships (MLPs), which are subject to the pass-through taxation system and Ccorporations, which are subject to the double taxation system. This research is particularly timely given ongoing debates about optimal tax policies and likely tax regime changes. The analysis begins by examining the theoretical change in value associated with tax rate changes followed by an analysis of the theoretical change in gains from leverage associated with tax rate changes. Next, we examine the theoretical implications of the 1986 Tax Reform Act (1986 TRA) on the gain from leverage. Finally, we test these implications using two paired samples of MLP's and CCorporations. 


\section{THEORETICAL CHANGES IN VALUATION}

The responses of firm values to changes in tax rates can be measured by taking the first derivative of the valuation and gain from leverage equations outlined above with respect to changes in the various tax rates. The analysis is completed first for DTFs then for PTFs. The partial derivative of the double taxation unlevered (Eq. 1) and levered (Eq. 2) equations with respect to changes in the corporate tax rate are respectively:

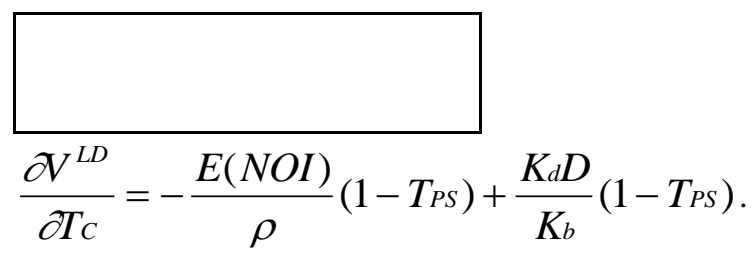

The value of the unlevered DTF will respond negatively to an increase in the entity-level tax rate while the response of an unlevered DTF to a change in entity-level tax rate is ambiguous, depending on the relative sizes the $E(N O I), \rho, K_{d}$, $D$, and $K_{b}$. The partial derivative of the double taxation unlevered (Eq. 1) and levered (Eq. 2) firms respectively with respect to a change in the personal tax rate on income from equity is:

$$
\begin{aligned}
& \frac{\partial V^{U D}}{\partial T_{P S}}=-\frac{E(N O I)}{\rho}\left(1-T_{C}\right) \\
& \frac{\partial V^{L D}}{\partial T_{P S}}=-\frac{E(N O I)}{\rho}\left(1-T_{C}\right)+\frac{K_{d} D}{K_{b}}\left(1-T_{C}\right) .
\end{aligned}
$$

The value of the unlevered DTF will respond negatively to a change in the personal tax rate on income from equity while the response of the levered DTF to a change in the personal tax rate on income from equity is ambiguous depending upon $E(N O I), \rho, K_{d}, D$, and $K_{b}$. Next, the partial derivative of the unlevered (Eq. 1) and levered (Eq. 2) DTFs respectively with respect to a change in the personal tax rate on income from bonds is:

$$
\begin{aligned}
& \frac{\partial V^{U D}}{\partial T_{P B}}=0 \\
& \frac{\partial V^{L D}}{\partial T_{P B}}=-\frac{K_{d} D}{K_{b}} .
\end{aligned}
$$

The value of the unlevered DTF should not be affected by a change in the personal tax rate on income from bonds however, the value of the levered DTF will respond negatively to a change in the personal tax rate on income from bonds.

Next, the analysis is completed for PTFs. The partial derivative of the pass-through taxation unlevered (Eq. 3) and levered (Eq. 4) equations with respect to a change in the personal tax rate on income from equity respectively are:

$$
\begin{aligned}
& \frac{\partial V^{U P}}{\partial T_{P S}}=-\frac{E(N O I)}{\rho} \\
& \frac{\partial V^{L P}}{\partial T_{P S}}=-\frac{E(N O I)}{\rho}+\frac{K_{d} D}{K_{b}}
\end{aligned}
$$


The value of the unlevered PTF is negatively related to the personal tax rate on equity income. The relationship between the value of the levered PTF and the personal tax rate on income from equity is ambiguous depending on the levels of $E(N O I), \rho, K_{D}, D$, and $K_{b}$. The partial derivatives of the value of the unlevered (Eq. 3) and levered (Eq. 4) PTF respectively with respect to a change in the personal tax rate on income from bonds are:

$$
\begin{aligned}
& \frac{\partial V^{U P}}{\partial \Gamma_{P B}}=0 \\
& \frac{\partial V^{L P}}{\partial T_{P B}}=-\frac{K_{d} D}{K_{b}} .
\end{aligned}
$$

The value of the unlevered PTF is not affected by a change in the personal tax rate on income from bonds while the value of the PTF is negatively related to the personal tax rate on income from bonds. Because the PTF does not pay the entity-level tax, entity-level taxes are not included in the valuation equations for the PTF. Thus, the value of the PTF will not be affected by changes in the entity-level tax.

\section{CHANGES IN GAINS FROM LEVERAGE}

The implied changes in the gain from leverage changes associated with tax rate change are examined first for DTFs then for PTFs. The partial derivative of the gain from leverage for a DTF (Eq. 5) with respect to changes in $T_{C}$, $T_{P S}$, and $T_{P B}$ respectively is given by the following equations:

$$
\begin{aligned}
& \frac{\partial G^{L D}}{\partial T_{C}}=\frac{K_{d} D}{K_{b}}\left(1-T_{P S}\right) \\
& \frac{\partial G^{L D}}{\partial T_{P S}}=\frac{K_{d} D}{K_{b}}\left(1-T_{C}\right) \\
& \frac{\partial G^{L D}}{\partial T_{P B}}=-\frac{K_{d} D}{K_{b}}
\end{aligned}
$$

The gain in leverage in a DTF is positively related to both the corporate tax rate and the personal tax rate while the gain from leverage in a DTF is negatively related to the personal tax rate on income from bonds. These findings are consistent with the findings of Bradley, Jarrell and Kim (1984) who incorporate bankruptcy costs and various assumptions in their model and demonstrate that the gain from leverage will be positively related to the personal tax rate on income from stocks.

The partial derivative of the gain from leverage in a PTF (Eq. 6) with respect to changes in $T_{C}, T_{P S}$, and $T_{P B}$ respectively is given by the following equations:

$$
\begin{aligned}
& \frac{\partial G^{L P}}{\partial \Gamma_{C}}=0 \\
& \frac{\partial G^{L P}}{\partial \Gamma_{P S}}=\frac{K_{d} D}{K_{b}} \\
& \frac{\partial G^{L P}}{\partial \Gamma_{P B}}=-\frac{K_{d} D}{K_{b}} .
\end{aligned}
$$

The gain from leverage in a PTF is not affected by a change in the entity-level tax rate. The gain from leverage in a PTF is positively related to the personal tax rate on income from equity. The gain from leverage in a PTF is negatively related to the personal tax rate on income from bonds. 


\section{THE 1986 TRA}

Utilizing the above equations, the theoretical change in the gain from leverage associated with the 1986 TRA can be identified. The tax reform act of 1986 reduced the highest marginal personal tax rate on ordinary income from 50 percent to 38.5 percent in 1987 and to 33 percent in 1988. The tax reform act of 1986 increased the highest marginal personal tax rate on capital gains from 20 percent to 28 percent. Corporate tax rates were reduced by the 1986 TRA. The top marginal corporate tax rate was lowered from about 50 percent to 45 percent in 1987 and to 39 percent for 1988 and subsequent years. In summary, the 1986 TRA reduced ordinary income tax rates, increased capital gains tax rates, and lowered corporate tax rates.

Because the personal tax rate on income from stocks, the personal tax rate on income from bonds and the corporate tax rates all underwent changes during this time period, the total differential of the gain from leverage for both the DTF and the PTF are examined with respect to changes in tax rates. These differentials indicate the change in the gain from leverage from simultaneous changes in tax rates, all else held constant. The total differential of the gain from leverage for the DTF with respect to a change in tax rates is given by:

$$
d G^{L D}=\frac{K_{d} D}{K_{b}}\left(1-T_{P S}\right) d T_{C}-\frac{K_{d} D}{K_{b}} d T_{P B}+\frac{K_{d} D}{K_{b}}\left(1-T_{C}\right) d T_{P S} .
$$

The decrease in corporate tax rates associated with the 1986 TRA implies a decrease in the gain from leverage for the DTF. The decrease in ordinary income tax rates (the personal tax rate on income from bonds) implies an increase in the gain from leverage for the DTF. The increase in the capital gains tax rate (the personal tax rate on income from equity) implies an increase in the gain from leverage for the DTF. Thus the effect of the 1986 TRA on the gain from leverage for the DTF is ambiguous depending on the magnitude of the corporate tax rate change relative to the magnitude of the change in personal tax rates on ordinary income and capital gains.

To examine the change in the gain from leverage for the PTF associated with the 1986 TRA, the total differential of the gain from leverage with respect to a change in tax rates is examined. The total differential of the gain from leverage for the PTF with respect to a change in tax rates is given by the following equation:

$$
d G^{L P}=0-\frac{K_{d} D}{K_{b}} d T_{P B}+\frac{K_{d} D}{K_{b}} d T_{P S}
$$

The change in the corporate tax rate associated with the 1986 TRA is not expected to affect the gain from leverage for the PTF. The decrease in the personal tax rate on ordinary income associated with the 1986 TRA increased the gain from leverage associated with the PTF. The increase in the personal tax rate on capital gains associated with the 1986 TRA is also increased the gain from leverage associated with the PTF. The combination of a decrease in the personal tax rate on income from bonds and an increase in the personal tax rate on income from stocks results in an unambiguous increase in the gain from leverage for PTFs.

Overall, the relative gain from leverage is expected to become larger for PTFs than for DTFs as a result of the 1986 TRA for two reasons. First, the decrease in corporate tax rates reduces the gain from leverage for DTFs, while it does not affect the gain from leverage for PTFs. Secondly, the increase in the gain from leverage associated with the increase in the personal tax rate on income from stocks is less for the DTFs than for the PTFs, because the gain is reduced by the amount $T_{C}$ for DTFs.

From the above observations, it is argued that the gain from leverage increased by more for PTFs than for DTFs as a result of the 1986 TRA. It is further argued that firm managers will attempt to take advantage of increased gains from leverage by increasing the debt level in their firms. Because the change in the gain from leverage is higher for PTFs relative to DTFs after the 1986 TRA, it is expected that PTFs to increase their leverage relative to C corporations around the 1986 TRA. This observation leads to the following testable hypothesis: 
Ho: The debt-to-assets (debt-to-equity) ratio for PTFs relative to the debt-to-assets (deb t- to-equity) ratio for DTFs did not change as a result of the tax rate changes associated with the 1986 TRA.

Ha: The debt-to-assets (debt-to-equity) ratio for PTFs relative to the debt-to-assets (debt - to-equity) ratio for DTFs increased as a result of the tax rate changes associated with the 1986 TRA.

\section{DATA AND METHODOLOGY}

The focus of the empirical section of this study is on the capital structure implications of the model developed in Jalbert (2002) as they relate to the 1986 TRA. In order to examine these implications a sample of PTFs and two samples of DTFs are compared. The sample of PTFs is MLPs taken from the Standard and Poor's Year-End Stock Guides and Compustat data file documentation. Those firms with names ending in L.P., partnership, or otherwise denoted as a MLP in the footnotes were selected. This procedure identified a sample of 94 MLPs that existed between 1983 and 1994. Two samples of domestic C corporations were selected for comparison to control for factors that have been shown to affect valuation and capital structure. Substantial evidence exists to suggest that industry; size and risk have an affect on firm valuation and the capital structure that the firm adopts (Titman and Wessels 1986, Banz 1981, Fama and French 1992, Shaw and Weir 1993, Guenther 1992 and others). The first sample of C corporations is the size-control group. The sample was created by selecting $\mathrm{C}$ corporations that most closely matched the industry, as measured by CIC code, and size, as measured by total assets, of each MLP. The second sample of C corporations is the risk-control group. The sample was created by selecting $\mathrm{C}$ corporations that most closely matched each MLPs industry, and risk, as measured by beta in accordance with Scholes and Williams (1977), of each MLP. Each firm pair was categorized as being a firm in the oil related industry, or a firm not in the oil related industry. This categorization is made because of unique accounting techniques applied to oil firms and because of the large losses that oil firms experienced in the 1980's (Harris \& Ohlson 1987 \& 1990, Shaw and Weir 1993, Magliano 1986 and others).

Annual data are collected for each firm from the Compustat data files, Standard and Poor's Corporate Reports and Moody's Bond Guides resulting in 624 annual data observations for each of the samples. Tax rate data are obtained from Henderson (1989) and were updated by examining Annual Internal Revenue Service Tax Guides. Yearend data on the yield for each bond rating is obtained from the Standard and Poor's December Bond Guide.

To test this implication of the model, the behavior of firms in the time period before and after passage of the 1986 TRA are examined. Two tests are conducted, an overall test and a yearly test. The overall test is intended to provide broad evidence of a change in capital structure while the yearly test is intended to identify more subtle changes that may have occurred. The overall test measures changes in debt level differences among firms that existed both prior and subsequent to the 1986 TRA. Thus only those firms that existed both prior and subsequent to 1986 are included in this analysis. The measure of debt is the debt-to-assets ratio and the debt-to-equity ratio. The average debt-to-assets (debt-to-equity) ratio for each firm is calculated for the years prior to the tax rate changes in 1987 and 1988 and for the years after the tax rate changes took effect. The average debt-to-assets (debt-to-equity) ratio prior to the tax reform act is calculated as the average debt-to-assets (debt-to-equity) ratio of the firm over the years 1984, 1985 and 1986. The average debt-to-assets (debt-to-equity) ratio after the tax reform act is calculated as the average debt-to-assets (debt-to-equity) ratio of the firm over the years 1989, 1990, and 1991. The unit of measurement is the change in the debt to equity ratio for each firm. Of interest is to determine if the median, debt-to-assets (debt-toequity) ratio for MLPs relative to C corporations increased as a result of the 1986 TRA as predicted. The one tailed Mann Whitney test is used to determine if the median difference in debt to equity ratios between DTFs and PTFs increased as a result of the 1986 tax rate changes.

The yearly test is completed using all of the firms that existed in a given year. In this analysis, firms that existed at any time during the sample period are analyzed. For this test, the variable of interest is the level of the debtto-assets (debt-to-equity) ratio. Again, the Mann Whitney test is used to determine if the median level of debt is different for MLP's and C-Corporations. In both the overall and yearly tests, the analysis is performed on the full sample as well as sub samples of oil industry firms and non-oil industry firms. The debt-to-equity tests are also performed using both the maximum marginal tax rate on ordinary income and the average marginal tax rate on ordinary income. As the results are quite similar, only the tests based on the maximum marginal tax rate are reported in this paper. 


\section{THE TEST RESULTS}

The results of the size-matched sample test are reported first followed by the risk-matched sample tests. The tables follow a common format. The first column reports the results of the overall test. The columns with year headings report the results of the yearly tests. The results of tests for changes in debt levels utilizing the size matched sample are reported in Tables 1 and 2. In Table 1, the debt-to-assets ratio is examined and in Table 2, the debt-toequity ratio is examined. In Panel A of Table 1, the test results for the full sample are presented, in panel B, the results of the test on the non-oil sub sample are reported and in Panel C, the results of the oil firm sub sample are reported. The overall tests provide no evidence of a change in debt levels around the 1986 TRA for the full sample or either of the sub samples. However, the yearly results do provide evidence of a change in debt levels. In the full sample, prior to 1986 there were no significant differences in debt levels, but in 1986 and subsequent years, significant differences are evident. Debt levels among MLPs increased from 18 percent in 1984 to 37 percent in 1994, while the debt levels of C-corporations remained relatively constant during the same time period. It should be noted that part of this result could be driven by a change in sample size. Despite the change in sample size however a shift in capital structure is apparent. In 1986, C-corporations had 11 percent more debt in their capital structures than MLPs. By 1994, the MLPs had 3 percent more debt in their capital structure than the C-corporations. In the non-oil sub sample it is clear that MLPs increased their levels of debt relative to C-corporations around the 1986 TRA. In 1984 and 1985, MLPs had only 18 and 13 percent debt respectively. In 1986, this level jumped to 22 percent and in 1987 to 28 percent. By 1994, the debt level had risen to 37 percent. During the same time period, the level of debt in the matched Ccorporations remained relatively constant. In the oil sub sample, a gradual increase in the debt level of MLP's relative to C-corporations is evident. The debt level of MLP's increased from 16 percent in 1984 to 37 percent in 1994 again with the level of debt among C-corporations remaining relatively constant during the same time period.

In Table 2, the results of the test on changes in debt levels utilizing the debt-to-equity measure of debt are reported. The overall test results are mixed. The overall test on the full sample and non-oil sub sample provide no evidence of a change in capital structure around the 1986 TRA. However, the overall test does indicate a significant change in the non-oil sub sample. The evidence indicates that the differential in debt levels was reduced as a result of the 1986 TRA. The results of the yearly tests on the full sample indicate a clear increase in debt levels among MLPs, with debt going from 3 percent of the capital structure in 1985 to 24 percent in 1994. The results are similar for both of the sub samples. Moreover, the bulk of the change occurs in the years 1986-1989 as would be expected if the capital structure adjustments are driven by a change in tax regimes as is suggested by the theory. While the debt-toassets test above indicated that MLPs used more debt in their capital structure, the evidence from the debt-to-equity tests suggest that while the debt levels of MLPs increased, they have not surpassed the levels of the C-corporations.

Next, we turn to the risk matched test results. The results are reported in Tables 3 and 4 . In Table 3, the debtto-assets ratio is examined and in Table 4, the debt-to-equity ratio is examined. The overall results presented in Table 3 provide no evidence of a change in debt levels around the 1986 TRA in the full sample or either of the sub samples. The results of the yearly tests for the full sample and both sub samples indicate a clear increase in the use of debt by MLPs relative to C-corporations. In each case, debt levels for MLP's go from the mid teen percentages to the high 30 percentages between 1984 and 1994. Again, the evidence indicates that by 1994, MLPs were using more debt in their capital structures than C-corporations.

The results of the test on changes in debt levels utilizing the debt-to-equity measure of debt are reported in Table 4. The overall test results provide no evidence of a change in debt levels around the 1986 TRA for the full sample or either of the sub samples. Similar to the results for the size matched sample, the yearly test results indicate a clear shift in capital structure among MLP relative to their matched C-corporation counterparts. This result holds for both the full sample and for both of the sub samples. Like the size matched results, the results here indicate that when measured by debt-to-equity levels, despite increasing, the debt levels of MLPs do not surpass those of C-corporations.

In general, the overall test results provide little evidence that debt level differentials were reduced in response to the 1986 TRA. However, the yearly tests provide strong evidence of a shift in capital structures around the 1986 TRA. Specifically, the evidence suggests that C-corporations maintained relatively constant debt levels around the 1986 TRA, while MLPs increased their debt levels substantially. 
Table 1: Changes in the debt-to-assets ratios and debt-to-assets ratio levels for the size matched sample around the 1986 TRA.

\begin{tabular}{|c|c|c|c|c|c|c|c|c|c|c|c|c|c|}
\hline Description & Overall & 83 & 84 & 85 & 86 & 87 & 88 & 89 & 90 & 91 & 92 & 93 & 94 \\
\hline $\begin{array}{l}\text { Panel A: } \\
\text { All Firms N } \\
\text { Median MLP } \\
\text { Median C co. } \\
\text { M.W. T } \\
\text { P-Value }\end{array}$ & $\begin{array}{l}43 \\
0.0129 \\
0.0138 \\
0.4169 \\
0.3398\end{array}$ & $\begin{array}{l}12 \\
0.3016 \\
0.4118 \\
-0.6571 \\
0.2654\end{array}$ & $\begin{array}{l}16 \\
0.1775 \\
0.3376 \\
-1.217 \\
0.1219\end{array}$ & \begin{tabular}{|l}
25 \\
0.2385 \\
0.2745 \\
-0.9401 \\
0.1781 \\
\end{tabular} & $\begin{array}{l}52 \\
0.2498 \\
0.3609 \\
-2.736 \\
0.0047^{* * *}\end{array}$ & \begin{tabular}{|l}
66 \\
0.2624 \\
0.3444 \\
-2.099 \\
$0.0202^{* *}$
\end{tabular} & $\begin{array}{l}68 \\
0.2581 \\
0.3528 \\
-2.510 \\
0.0076^{* * *}\end{array}$ & \begin{tabular}{|l}
63 \\
0.2671 \\
0.3636 \\
-2.373 \\
$0.0108^{* *}$
\end{tabular} & $\begin{array}{l}62 \\
0.3049 \\
0.3501 \\
-2.172 \\
0.0173^{* *}\end{array}$ & \begin{tabular}{|l}
64 \\
0.2765 \\
0.3687 \\
-2.056 \\
$0.0223^{* *}$
\end{tabular} & $\begin{array}{l}65 \\
0.3196 \\
0.3832 \\
-1.643 \\
0.0528^{*}\end{array}$ & $\begin{array}{l}65 \\
0.3343 \\
0.3701 \\
-1.230 \\
0.1114\end{array}$ & $\begin{array}{l}60 \\
0.3712 \\
0.3384 \\
-0.5916 \\
0.2780\end{array}$ \\
\hline $\begin{array}{l}\text { Panel B: } \\
\text { Non-Oil N } \\
\text { Median MLP } \\
\text { Median C co. } \\
\text { M.W. T } \\
\text { P-Value } \\
\end{array}$ & $\begin{array}{l}27 \\
0.0171 \\
0.0092 \\
0.7147 \\
0.2460 \\
\end{array}$ & \begin{tabular}{|l}
8 \\
0.3016 \\
0.4202 \\
-0.4086 \\
0.3559 \\
\end{tabular} & \begin{tabular}{|l}
10 \\
0.1811 \\
0.3817 \\
-0.7482 \\
0.2404 \\
\end{tabular} & \begin{tabular}{|l}
12 \\
0.1383 \\
0.3680 \\
-0.9816 \\
0.1752 \\
\end{tabular} & \begin{tabular}{|l}
32 \\
0.2240 \\
0.3777 \\
-2.052 \\
$0.0252^{* *}$ \\
\end{tabular} & \begin{tabular}{|l}
46 \\
0.2893 \\
0.3397 \\
-1.376 \\
$0.0878^{*}$ \\
\end{tabular} & \begin{tabular}{|l}
46 \\
0.2364 \\
0.3450 \\
-2.105 \\
$0.0210^{* *}$ \\
\end{tabular} & \begin{tabular}{|l}
42 \\
0.2793 \\
0.3608 \\
-2.100 \\
$0.0216^{* *}$ \\
\end{tabular} & $\begin{array}{l}44 \\
0.3288 \\
0.3872 \\
-1.836 \\
0.0371^{* *} \\
\end{array}$ & \begin{tabular}{|l}
44 \\
0.3396 \\
0.3910 \\
-1.565 \\
$0.0626^{*}$ \\
\end{tabular} & \begin{tabular}{|l}
46 \\
0.3313 \\
0.3868 \\
-1.135 \\
0.1309 \\
\end{tabular} & $\begin{array}{l}46 \\
0.3589 \\
0.3725 \\
-0.7091 \\
0.2407\end{array}$ & \begin{tabular}{|l}
44 \\
0.3712 \\
0.3343 \\
-0.3156 \\
0.3775 \\
\end{tabular} \\
\hline $\begin{array}{l}\text { Panel C: } \\
\text { Oil Firms N } \\
\text { Median MLP } \\
\text { Median C co. } \\
\text { M.W. T } \\
\text { P-Value } \\
\end{array}$ & $\begin{array}{l}16 \\
0.0002 \\
0.0228 \\
-0.1113 \\
0.5373 \\
\end{array}$ & \begin{tabular}{|l}
4 \\
0.2718 \\
0.3523 \\
-0.4089 \\
0.3900 \\
\end{tabular} & \begin{tabular}{|l}
6 \\
0.1645 \\
0.2815 \\
-0.7866 \\
0.2431 \\
\end{tabular} & \begin{tabular}{|l}
13 \\
0.2621 \\
0.2616 \\
-0.1760 \\
0.4395 \\
\end{tabular} & \begin{tabular}{|l}
20 \\
0.2598 \\
0.3573 \\
-1.749 \\
$0.0495^{* *}$
\end{tabular} & $\begin{array}{l}20 \\
0.2445 \\
0.3545 \\
-1.779 \\
0.0469^{* *} \\
\end{array}$ & $\begin{array}{l}22 \\
0.2605 \\
0.3973 \\
-1.400 \\
0.0884^{* *}\end{array}$ & \begin{tabular}{|l|}
21 \\
0.2671 \\
0.3841 \\
-1.201 \\
0.1220 \\
\end{tabular} & $\begin{array}{l}18 \\
0.2919 \\
0.3232 \\
-1.013 \\
0.1629 \\
\end{array}$ & \begin{tabular}{|l}
20 \\
0.2412 \\
0.3405 \\
-1.340 \\
$0.0985^{*}$ \\
\end{tabular} & $\begin{array}{l}19 \\
0.3044 \\
0.3467 \\
-1.343 \\
0.1252 \\
\end{array}$ & $\begin{array}{l}19 \\
0.3232 \\
0.3379 \\
-1.189 \\
0.1252 \\
\end{array}$ & \begin{tabular}{|l}
16 \\
0.3771 \\
0.3405 \\
-0.8249 \\
0.2120 \\
\end{tabular} \\
\hline
\end{tabular}

indicates significance at the 10 percent level, ${ }^{* *}$ indicates significance at the 5 percent level, ${ }^{* * *}$ indicates significance at the 1 percent level

Table 2: Change in the debt-to-equity ratios and debt-to-equity ratio levels for the size matched sample

\begin{tabular}{|c|c|c|c|c|c|c|c|c|c|c|c|c|c|}
\hline Description & Overall & 83 & 84 & 85 & 86 & 87 & 88 & 89 & 90 & 91 & 92 & 93 & 94 \\
\hline $\begin{array}{l}\text { Panel A: } \\
\text { All Firms N } \\
\text { Median MLP } \\
\text { Median C co. } \\
\text { M.W. T } \\
\text { P-Value } \\
\end{array}$ & $\begin{array}{l}32 \\
0.0103 \\
-0.0103 \\
1.199 \\
0.1196\end{array}$ & $\begin{array}{l}11 \\
0.0970 \\
0.2393 \\
-1.838 \\
0.0511^{*}\end{array}$ & $\begin{array}{l}14 \\
0.0761 \\
0.2170 \\
-2.041 \\
0.0336^{* *}\end{array}$ & $\begin{array}{l}22 \\
0.0360 \\
0.1693 \\
-3.309 \\
0.0025^{* * *}\end{array}$ & \begin{tabular}{|l}
40 \\
0.0618 \\
0.2743 \\
-3.576 \\
$0.0007^{* * *}$ \\
\end{tabular} & $\begin{array}{l}59 \\
0.1020 \\
0.3096 \\
-3.208 \\
0.0013^{* * *}\end{array}$ & $\begin{array}{l}65 \\
0.1243 \\
0.3960 \\
-3.773 \\
0.0003^{* * *}\end{array}$ & \begin{tabular}{|l|}
60 \\
0.1696 \\
0.4047 \\
-3.252 \\
$0.0011^{\text {*** }}$ \\
\end{tabular} & \begin{tabular}{|l}
61 \\
0.1741 \\
0.3805 \\
-3.252 \\
$0.0003^{* * *}$ \\
\end{tabular} & \begin{tabular}{|l}
60 \\
0.1823 \\
0.3763 \\
-3.708 \\
$0.0004^{* * *}$ \\
\end{tabular} & \begin{tabular}{|l}
63 \\
0.1427 \\
0.3831 \\
-3.620 \\
$0.0019^{* * *}$ \\
\end{tabular} & \begin{tabular}{|l}
62 \\
0.1213 \\
0.3280 \\
-3.052 \\
$0.0010^{* * *}$ \\
\end{tabular} & $\begin{array}{l}59 \\
0.2393 \\
0.2655 \\
-3.277 \\
0.0027^{* * *}\end{array}$ \\
\hline $\begin{array}{l}\text { Panel B: } \\
\text { Non-Oil N } \\
\text { Median MLP } \\
\text { Median C co. } \\
\text { M.W. T } \\
\text { P-Value }\end{array}$ & $\begin{array}{l}19 \\
0.0120 \\
0.0107 \\
0.4476 \\
0.3320\end{array}$ & $\begin{array}{l}7 \\
0.1149 \\
0.2393 \\
-0.5602 \\
0.3088\end{array}$ & $\begin{array}{l}8 \\
0.0761 \\
0.2390 \\
-0.9423 \\
0.1929\end{array}$ & $\begin{array}{l}11 \\
0.0053 \\
0.1641 \\
-2.854 \\
0.0120^{* *}\end{array}$ & \begin{tabular}{|l}
22 \\
0.0145 \\
0.1800 \\
-3.186 \\
$0.0031^{* * *}$
\end{tabular} & $\begin{array}{l}39 \\
0.1020 \\
0.2416 \\
-2.428 \\
0.0107^{* *}\end{array}$ & $\begin{array}{l}44 \\
0.1161 \\
0.3201 \\
-3.374 \\
0.0010^{* * *}\end{array}$ & $\begin{array}{l}41 \\
0.1356 \\
0.4030 \\
-3.174 \\
0.0018^{* * *}\end{array}$ & $\begin{array}{l}44 \\
0.1645 \\
0.3446 \\
-3.334 \\
0.0011^{\text {*** }}\end{array}$ & \begin{tabular}{|l}
43 \\
0.1500 \\
0.4001 \\
-3.248 \\
$0.0014^{* * *}$
\end{tabular} & \begin{tabular}{|l}
44 \\
0.1207 \\
0.4437 \\
-3.000 \\
$0.0026^{* * *}$
\end{tabular} & $\begin{array}{l}43 \\
0.1153 \\
0.3822 \\
-3.228 \\
0.0015^{\text {*** }}\end{array}$ & $\begin{array}{l}44 \\
0.1014 \\
0.2636 \\
-2.824 \\
0.0040^{* * *}\end{array}$ \\
\hline $\begin{array}{l}\text { Panel C: } \\
\text { Oil Firms N } \\
\text { Median MLP } \\
\text { Median C co. } \\
\text { M.W. T } \\
\text { P-Value }\end{array}$ & $\begin{array}{l}13 \\
0.0038 \\
-0.0539 \\
1.497 \\
0.0817^{*}\end{array}$ & $\begin{array}{l}4 \\
0.0616 \\
0.3020 \\
-2.898 \\
0.0514^{*}\end{array}$ & $\begin{array}{l}6 \\
0.0900 \\
0.1709 \\
-1.743 \\
0.0782^{*}\end{array}$ & $\begin{array}{l}11 \\
0.0456 \\
0.1745 \\
-1.599 \\
0.0730^{*}\end{array}$ & $\begin{array}{l}18 \\
0.1032 \\
0.3818 \\
-1.939 \\
0.0363^{* *}\end{array}$ & $\begin{array}{l}20 \\
0.1025 \\
0.3817 \\
-2.086 \\
0.0269^{* *}\end{array}$ & $\begin{array}{l}21 \\
0.1412 \\
0.5155 \\
-1.547 \\
0.0695^{*}\end{array}$ & $\begin{array}{l}19 \\
0.2219 \\
0.4064 \\
-1.068 \\
0.1500\end{array}$ & \begin{tabular}{|l}
17 \\
0.2263 \\
0.4403 \\
-1.604 \\
$0.0654^{*}$
\end{tabular} & $\begin{array}{l}17 \\
0.2498 \\
0.3441 \\
-1.528 \\
0.0740\end{array}$ & $\begin{array}{l}19 \\
0.2251 \\
0.3082 \\
-1.038 \\
0.1567\end{array}$ & $\begin{array}{l}19 \\
0.2280 \\
0.2632 \\
-0.7105 \\
0.2440\end{array}$ & $\begin{array}{l}15 \\
0.2482 \\
0.2771 \\
-0.8885 \\
0.1955\end{array}$ \\
\hline
\end{tabular}

indicates significance at the 10 percent level, ${ }^{* *}$ indicates significance at the 5 percent level, ${ }^{* * * *}$ indicates significance at the 1 percent level 
Table 3: Changes in the debt-to-assets ratios and debt-to-assets levels for the risk matched sample test.

\begin{tabular}{|c|c|c|c|c|c|c|c|c|c|c|c|c|c|}
\hline Description & Overall & 83 & 84 & 85 & 86 & 87 & 88 & 89 & 90 & 91 & 92 & 93 & 94 \\
\hline $\begin{array}{l}\text { Panel A: } \\
\text { All Firms N } \\
\text { Median MLP } \\
\text { Median C co. } \\
\text { M.W. T } \\
\text { P-Value } \\
\end{array}$ & $\begin{array}{l}43 \\
0.0129 \\
0.0206 \\
0.4944 \\
0.3119 \\
\end{array}$ & \begin{tabular}{|l|}
12 \\
0.3016 \\
0.2674 \\
-0.5117 \\
0.3140 \\
\end{tabular} & \begin{tabular}{|l|}
16 \\
0.1774 \\
0.2977 \\
-1.177 \\
0.1294 \\
\end{tabular} & $\begin{array}{l}25 \\
0.2385 \\
0.3098 \\
-1.628 \\
0.0589^{*} \\
\end{array}$ & \begin{tabular}{|l}
52 \\
0.2498 \\
0.3550 \\
-2.779 \\
$0.0042^{* * *}$ \\
\end{tabular} & \begin{tabular}{|l}
66 \\
0.2624 \\
0.3654 \\
-3.034 \\
$0.0019^{* * *}$ \\
\end{tabular} & $\begin{array}{l}67 \\
0.2586 \\
0.3533 \\
-2.601 \\
0.0060^{* * *} \\
\end{array}$ & \begin{tabular}{|l}
61 \\
0.2671 \\
0.3475 \\
-2.036 \\
$0.0023^{* * *}$ \\
\end{tabular} & \begin{tabular}{|l}
62 \\
0.3050 \\
0.3348 \\
-1.482 \\
$0.0718^{*}$ \\
\end{tabular} & \begin{tabular}{|l}
64 \\
0.2765 \\
0.3483 \\
-1.310 \\
$0.0974^{*}$ \\
\end{tabular} & $\begin{array}{l}65 \\
0.3196 \\
0.3393 \\
-0.5832 \\
0.2806 \\
\end{array}$ & \begin{tabular}{|l}
66 \\
0.3358 \\
0.3387 \\
-0.1906 \\
0.4352 \\
\end{tabular} & $\begin{array}{l}62 \\
0.3908 \\
0.3325 \\
0.1593 \\
0.5625 \\
\end{array}$ \\
\hline $\begin{array}{l}\text { Panel B: } \\
\text { Non-Oil N } \\
\text { Median MLP } \\
\text { Median C co. } \\
\text { M.W. T } \\
\text { P-Value } \\
\end{array}$ & $\begin{array}{l}27 \\
0.0234 \\
0.0616 \\
0.0600 \\
0.4794 \\
\end{array}$ & \begin{tabular}{|l}
8 \\
0.3016 \\
0.2674 \\
-0.4086 \\
0.3590 \\
\end{tabular} & \begin{tabular}{|l}
10 \\
0.1811 \\
0.2647 \\
-0.8258 \\
0.2182 \\
\end{tabular} & $\begin{array}{l}12 \\
0.1383 \\
0.2937 \\
-1.1031 \\
0.1480 \\
\end{array}$ & \begin{tabular}{|l}
32 \\
0.2240 \\
0.3550 \\
-1.892 \\
$0.0346^{* *}$ \\
\end{tabular} & \begin{tabular}{|l}
46 \\
0.2893 \\
0.3591 \\
-2.465 \\
$0.0093^{* * *}$ \\
\end{tabular} & $\begin{array}{l}45 \\
0.2575 \\
0.3533 \\
-2.528 \\
0.0081^{* * *} \\
\end{array}$ & \begin{tabular}{|l}
40 \\
0.2793 \\
0.3678 \\
-2.335 \\
$0.0130^{* *}$ \\
\end{tabular} & $\begin{array}{l}44 \\
0.3288 \\
0.3800 \\
-1.531 \\
0.0666^{*} \\
\end{array}$ & \begin{tabular}{|l|}
44 \\
0.3396 \\
0.3901 \\
-0.9089 \\
0.1838 \\
\end{tabular} & $\begin{array}{l}46 \\
0.3313 \\
0.3716 \\
-0.3423 \\
0.3673 \\
\end{array}$ & \begin{tabular}{|l}
7 \\
0.3804 \\
0.3536 \\
-0.0339 \\
0.4879 \\
\end{tabular} & $\begin{array}{l}46 \\
0.3908 \\
0.3271 \\
-0.0855 \\
0.5326 \\
\end{array}$ \\
\hline $\begin{array}{l}\text { Panel C: } \\
\text { Oil Firms N } \\
\text { Median MLP } \\
\text { Median C co. } \\
\text { M.W. T } \\
\text { P-Value } \\
\end{array}$ & $\begin{array}{l}16 \\
0.0002 \\
-0.0018 \\
0.9793 \\
0.1720 \\
\end{array}$ & \begin{tabular}{|l}
4 \\
0.2718 \\
0.3289 \\
-0.5477 \\
0.3390 \\
\end{tabular} & \begin{tabular}{|l}
6 \\
0.1644 \\
0.3511 \\
-0.9571 \\
0.1986 \\
\end{tabular} & $\begin{array}{l}13 \\
0.2621 \\
0.3441 \\
-1.162 \\
0.1349 \\
\end{array}$ & $\begin{array}{l}20 \\
0.2598 \\
0.3597 \\
-2.023 \\
0.0302^{* *} \\
\end{array}$ & \begin{tabular}{|l}
20 \\
0.2445 \\
0.3654 \\
-1.748 \\
$0.0494^{* *}$ \\
\end{tabular} & $\begin{array}{l}22 \\
0.2605 \\
0.3686 \\
-0.8184 \\
0.2112 \\
\end{array}$ & \begin{tabular}{|l|}
21 \\
0.2671 \\
0.3400 \\
-0.2362 \\
0.4110 \\
\end{tabular} & \begin{tabular}{|l}
18 \\
0.2919 \\
0.3108 \\
-0.3750 \\
0.3591 \\
\end{tabular} & \begin{tabular}{|l}
20 \\
0.2412 \\
0.3136 \\
-1.085 \\
0.1459 \\
\end{tabular} & $\begin{array}{l}19 \\
0.3044 \\
0.3286 \\
-0.7399 \\
0.2350 \\
\end{array}$ & \begin{tabular}{|l}
19 \\
0.3232 \\
0.3198 \\
-0.3317 \\
0.3750 \\
\end{tabular} & $\begin{array}{l}16 \\
0.3771 \\
0.3358 \\
-0.0371 \\
0.5075 \\
\end{array}$ \\
\hline
\end{tabular}

indicates significance at the 10 percent level, ${ }^{* *}$ indicates significance at the 5 percent level, ${ }^{* * *}$ indicates significance at the 1 percent level

Table 4: Changes in the debt-to-equity ratios and debt-to-equity levels for the Risk matched sample.

\begin{tabular}{|c|c|c|c|c|c|c|c|c|c|c|c|c|c|}
\hline Description & Overall & 83 & 84 & 85 & 86 & 87 & 88 & 89 & 90 & 91 & 92 & 93 & 94 \\
\hline $\begin{array}{l}\text { Panel A: } \\
\text { All Firms N } \\
\text { Median MLP } \\
\text { Median C co. } \\
\text { M.W. T } \\
\text { P-Value } \\
\end{array}$ & $\begin{array}{l}31 \\
0.0120 \\
0.0124 \\
-0.1746 \\
0.4332 \\
\end{array}$ & $\begin{array}{l}11 \\
0.0970 \\
0.1582 \\
-1.127 \\
0.1448 \\
\end{array}$ & $\begin{array}{l}14 \\
0.0761 \\
0.2132 \\
-2.213 \\
0.0253^{* *}\end{array}$ & \begin{tabular}{|l}
22 \\
0.0360 \\
0.1844 \\
-3.791 \\
$0.0010^{* * * *}$ \\
\end{tabular} & $\begin{array}{l}39 \\
0.0616 \\
0.1902 \\
-2.952 \\
0.0032^{* * *} \\
\end{array}$ & $\begin{array}{l}60 \\
0.1007 \\
0.2421 \\
-3.357 \\
0.0009^{* * *} \\
\end{array}$ & $\begin{array}{l}65 \\
0.1119 \\
0.2702 \\
-3.126 \\
0.0015^{* * *} \\
\end{array}$ & \begin{tabular}{|l}
60 \\
0.1575 \\
0.2854 \\
-2.579 \\
$0.0066^{* * *}$ \\
\end{tabular} & $\begin{array}{l}60 \\
0.1673 \\
0.2746 \\
-2.988 \\
0.0023^{* * *} \\
\end{array}$ & \begin{tabular}{|l}
60 \\
0.1557 \\
0.2716 \\
-2.421 \\
$0.0097^{* *}$ \\
\end{tabular} & $\begin{array}{l}63 \\
0.1427 \\
0.2707 \\
-1.901 \\
0.0313^{* *}\end{array}$ & $\begin{array}{l}63 \\
0.1252 \\
0.2084 \\
-1.639 \\
0.0533^{* *}\end{array}$ & $\begin{array}{l}60 \\
0.1441 \\
0.2207 \\
-1.726 \\
0.0451^{* *}\end{array}$ \\
\hline $\begin{array}{l}\text { Panel B: } \\
\text { Non-Oil N } \\
\text { Median MLP } \\
\text { Median C co. } \\
\text { M.W. T } \\
\text { P-Value } \\
\end{array}$ & $\begin{array}{l}19 \\
0.0120 \\
0.1580 \\
-1.626 \\
0.9383 \\
\end{array}$ & $\begin{array}{l}7 \\
0.1149 \\
0.1787 \\
-0.8210 \\
0.2283 \\
\end{array}$ & $\begin{array}{l}8 \\
0.0761 \\
0.2483 \\
-1.537 \\
0.0882^{*} \\
\end{array}$ & \begin{tabular}{|l}
11 \\
0.0053 \\
0.2016 \\
-3.440 \\
$0.0059^{* * *}$ \\
\end{tabular} & $\begin{array}{l}22 \\
0.0145 \\
0.1646 \\
-2.635 \\
0.0091^{* * *} \\
\end{array}$ & $\begin{array}{l}40 \\
0.0997 \\
0.2375 \\
-2.711 \\
0.0055^{* * *} \\
\end{array}$ & $\begin{array}{l}44 \\
0.1066 \\
0.2988 \\
-3.314 \\
0.0012^{* * *} \\
\end{array}$ & \begin{tabular}{|l}
41 \\
0.1289 \\
0.3016 \\
-3.152 \\
$0.0019^{* * * *}$ \\
\end{tabular} & $\begin{array}{l}43 \\
0.1549 \\
0.3016 \\
-2.966 \\
0.0029^{* * *} \\
\end{array}$ & \begin{tabular}{|l}
42 \\
0.1410 \\
0.2765 \\
-2.148 \\
$0.0195^{* *}$ \\
\end{tabular} & $\begin{array}{l}44 \\
0.1207 \\
0.2725 \\
-1.836 \\
0.0371^{* *} \\
\end{array}$ & $\begin{array}{l}44 \\
0.1164 \\
0.2348 \\
-1.601 \\
0.0586^{*} \\
\end{array}$ & $\begin{array}{l}44 \\
0.1028 \\
0.2118 \\
-1.793 \\
0.0405\end{array}$ \\
\hline $\begin{array}{l}\text { Panel C: } \\
\text { Oil Firms N } \\
\text { Median MLP } \\
\text { Median C co. } \\
\text { M.W. T } \\
\text { P-Value }\end{array}$ & $\begin{array}{l}12 \\
0.0439 \\
-0.0181 \\
1.288 \\
0.1135\end{array}$ & $\begin{array}{l}4 \\
0.0616 \\
0.1060 \\
-0.6990 \\
0.2898\end{array}$ & $\begin{array}{l}6 \\
0.0900 \\
0.1911 \\
-1.526 \\
0.1004 \\
\end{array}$ & $\begin{array}{l}11 \\
0.0456 \\
0.1672 \\
-1.917 \\
0.4540 \\
\end{array}$ & $\begin{array}{l}17 \\
0.1005 \\
0.2192 \\
-1.528 \\
0.7410 \\
\end{array}$ & \begin{tabular}{|l}
20 \\
0.1017 \\
0.2654 \\
-1.869 \\
$0.0399^{* *}$ \\
\end{tabular} & $\begin{array}{l}21 \\
0.1192 \\
0.2591 \\
-0.8142 \\
0.2128 \\
\end{array}$ & $\begin{array}{l}19 \\
0.2219 \\
0.2271 \\
-0.1296 \\
0.4539 \\
\end{array}$ & $\begin{array}{l}17 \\
0.2263 \\
0.2498 \\
-0.8402 \\
0.2072 \\
\end{array}$ & $\begin{array}{l}18 \\
0.2265 \\
0.2335 \\
-0.9478 \\
0.1785\end{array}$ & $\begin{array}{l}19 \\
0.2251 \\
0.2034 \\
-0.5641 \\
0.2912 \\
\end{array}$ & $\begin{array}{l}19 \\
0.2280 \\
0.1844 \\
-0.3028 \\
0.3896\end{array}$ & $\begin{array}{l}16 \\
0.2506 \\
0.2274 \\
-0.1855 \\
0.4332 \\
\end{array}$ \\
\hline
\end{tabular}

indicates significance at the 10 percent level, ${ }^{* *}$ indicates significance at the 5 percent level, ${ }^{* * *}$ indicates significance at the 1 percent level 


\section{CONCLUSIONS}

In this paper we analyze the theoretical changes in firm value and gains from leverage associated with tax rate changes. The theoretical changes are based on a valuation model developed in Jalbert (2002). The implied changes in capital structure are examined by using a sample of MLP's along with two, matched samples of Ccorporations. Two tests are conducted, an overall test and a yearly test. The overall test provides little evidence of a capital structure change around the 1986 TRA. The yearly tests provide strong evidence of a capital structure shift around the 1986 TRA. Specifically, MLPs are found to have increased the use of debt in conjunction with the 1986 TRA as was predicted by the theory.

This research provides managers with a theoretical foundation to determine the expected change in firm value associated with a tax rate change. Moreover, this work provides insights to managers about if, and the extent to which their capital structures should be modified in response to a tax rate change. Finally, the model provides a theoretical framework to determine appropriate capital structure changes when tax rates are expected to change. This research will also be useful for policy makers who set tax rates. By examining the changes in the gain from leverage associated with various tax schemes and setting tax rates accordingly, policymakers can encourage the uses of preferable sources of financing in the economy. If there is a public utility to be gained from a given aggregate financing scheme in firms, this research will help policy makers set tax rates in such a manner to encourage firms to finance themselves in this pattern.

\section{REFERENCES}

1. Banz, R. W. (1981) The Relationship between Return and Market Value of Common Stocks, Journal of Financial Economics, March, p. 3-18.

2. Bradley, Michael, Gregg A. Jarrell and E. Han Kim (1984) On the Existence of an Optimal Capital Structure: Theory and Evidence, The Journal of Finance, July, p. 857-878.

3. Fama, Eugene and Kenneth R. French (1992) The Cross Section of Expected Stock Returns, Journal of Finance, June, p. 427-465.

4. Guenther, David A. (1992) Taxes and Organizational Form: A Comparison of Corporations and MLPs, The Accounting Review, January, p. 17-45.

5. Harris, Trevor S. and James A. Ohlson (1987) Accounting Disclosures and the Market's Valuation of Oil and Gas Properties, The Accounting Review, October, p. 651-670.

6. Harris, Trevor S. and James A. Ohlson (1990) Accounting Disclosures and the Market's Valuation of Oil and Gas Properties: Evaluation of Market Efficiency and Functional Fixation, The Accounting Review, October, p. 764-780.

7. Henderson, Yolanda (1989) Capital Gains Rates and Revenues, New England Economic Review, January/February, p. 3-20.

8. Jalbert, Terrance (2002) Pass-Through Taxation and the Value of the Firm, The American Business Review, Vol. 20(2), June, p. 47-54.

9. Jalbert, Terrance and William Dukes (2003) Comparative Valuation and the Effect of the Bush Tax Proposal, Business Valuation Resources, Vol. 9(3), March, p. 1-6.

10. Magliano, Joseph (1986) Capital Market Analysis of Reserve Recognition Accounting, Journal of Accounting Research, Supplement, p. 69-108.

11. Miller, Merton (1977) Debt and Taxes, Journal of Finance, May, p. 261-275.

12. Scholes, Myron and Joseph Williams (1977) Estimating Betas from Nonsynchronous Data, Journal of Financial Economics, vol. 5, p. 309-327.

13. Shaw Wayne H. and Heather A. Wier (1993) Organizational Form Choice and the Valuation of Oil and Gas Producers, The Accounting Review, July, p. 657-667.

14. Standard and Poor's-corporation, Bond Guide, New York, December issues, 1984-1993

15. Standard and Poor's-corporation, COMPUSTAT II Data Files and Associated Documentation, New York.

16. Standard and Poor's-corporation, Memo 30 - Limited Partnerships - Special Industry Definitions, New York, General Procedures Manual, January 1991, p. 1-6.

17. Standard and Poor's-corporation (1984-1993) Stock Guide, New York, Year end issues Titman Sheridan and Roberto Wessels (1986) The Determinants of Capital Structure Choice, Working Paper, UCLA, January. 